\title{
Obliterating creative capital? Urban governance of creative industries in post-socialist Budapest
}

\author{
Márton Czirfusz \\ Institute for Regional Studies \\ Centre for Economic and Regional Studies \\ Hungarian Academy of Sciences \\ Budaörsi út 45., 1112 Budapest, Hungary \\ czirfusz@rkk.hu
}

\begin{abstract}
One of the disguises of the entrepreneurial city reaching Eastern Europe is what is called the creativity thesis. The author first points out that the idea of the creative city / creative capital has arrived in Hungary without any critical voices heard. He then goes on to evaluate some of the recent urban developments in Budapest linked to the idea of creativity. The paper argues that the idea of creative capital has been translated into development practices differently in the Hungarian context, which has also resulted in the obliteration of creative capital. Finally, the author underlines the importance of new perspectives in counteracting the hegemony of the creative capital thesis.
\end{abstract}

Keywords: creative city, urban governance, neoliberalism, policy mobilities, Budapest.

\section{Introduction}

Post-socialism has transformed urban and regional space-economies throughout Eastern Europe. After 1990, on the urban scale capitalist development infiltrated social structures and manifested itself materially in the urban built environment. As a result, urban policy-makers found themselves in completely new economic and power constellations which necessitated new answers to these emerging challenges.

Studies on the 'Western logic' of urban development show that one of the main forms how urban policy-makers reconciled with the shifts towards urban neoliberalism in the past decades is the idea of the 'entrepreneurial city' (Harvey 1989). In the Eastern European context after 1990, the democratically elected local governments embarked on capitalising on the real estate owned by them, introducing new ways of urban governance (imposed by the EU regulations and different national and international advocacy groups) and re-territorialising their activities under the new regulations and the new state structure. This reshuffling, however, has been rendered opaque in many cases, its underlying logic is hidden from the people living in the city. For instance, the entrepreneurial city as an idea has been disguised by various human and non-human actors in urban development practices. The imported idea of the 'creative city' is one of these disguises. In this case, the main tenet of the 
concept - that the rise of the creative capital in the city will result in wealth and prosperity for all local citizens - is not challenged by any actors of urban development, as it is politically unimaginable to attack a policy which contributes to the well-being of people.

In many Eastern European cities advocating the creative city idea and nurturing the creative capital located in the urban neighbourhoods have been an important agenda of the policy-makers. Consequently, most of the recent studies dealing with this topic in the context of Eastern European urban governance have focused on the positive aspects of this shift (for example Egedy\&Kovács 2010). By contrast, there is almost no scientific discussion on what creative capital means in specific Eastern European economic contexts, how this concept might be used in studies in non-Western social realities, and how anchoring urban development to creativity inadvertently leads to a selective interpretation of the concept.

The aims of this article are threefold. Firstly, the paper discusses in detail how the concept of creative capital is inextricably blended with the entrepreneurial city. This part rethinks debates of the international literature in urban studies for our common post-socialist realities. Secondly, the article shows how selectively the creative city / creative capital thesis has travelled to Hungary, especially the capital city, Budapest. As the policy mobilities literature of recent years offers a useful entry point for these discussions, the paper extends those theoretical considerations and empirical studies to the Eastern European context. Thirdly, this article is to evaluate critically some of recent urban developments in Budapest which are linked to the creativity idea in different ways. The argument will be that the creative capital and the creative city idea is a broad concept which might be translated into urban development practices in very different ways - in many cases resulting in an obliteration of creativity in the city. The conclusion outlines some crucial issues for Eastern European urban studies and offers new perspectives for counteracting the hegemony and selectivity of the creative capital thesis.

\section{Post-socialist entrepreneurial cities under capitalism}

In his classic writing, David Harvey (1989) analyses the reasons why the entrepreneurial stance in urban governance has been prevailing since the 1970s in the West. The entrepreneurial change has manifested itself in various forms in the capitalist world (though David Harvey's examples are mostly from North America and Great Britain). For the argument of this writing it is important to underline that producing new places, upgrading the image of cities or neighbourhoods often builds on cultural projects. As Harvey (1989: 9) writes, 'the city has to appear as an innovative, exciting, creative, and safe place to live or to visit, to play and consume in'. He concludes that under the capitalist mode of regulation these kinds of projects render urban social and economic problems opaque.

Yet, this line of argument by Harvey is only relevant to understanding of urban development in Eastern Europe if the cities in this region share capitalist conditions with their counterparts in the West. This is not the place to attempt a full overview of whether (or to what extent) the Eastern European cities of the $21^{\text {st }}$ century are capitalist. But it is certainly true that it is only under certain social conditions that Harvey's ideas might explain post-socialist urban development. In her book, Judit Bodnár (2001) differentiates between three strands in the literature how socialist and postsocialist urban development might be theorised vis-à-vis the 'Western' capitalist one. Finally, she suggests that urban studies shall opt for a comparative strategy which will enable valid explanations of similarities and differences, relations and dependencies. Thus, Eastern European cities might 
be understood as capitalist cities, but there should be room for explaining prevailing structures inherited from the Socialist period. This comparative understanding is also in line with recent methodological reflections on policy mobilities (Peck \& Theodore 2012) which will be discussed later in this paper.

To bring the argument forward, if contemporary Eastern European cities are developing under capitalism, it is then valid to look at how entrepreneurialism in general, and development led by creativity and culture in particular have penetrated urban structures in the region. Many authors have discussed the different roles globalisation played for different actors in the past 25 years of Eastern European urban development (Földi\&Weesep 2007; Nagy\&Timár 2012; Petrovici 2012; Sýkora\&Bouzarovski 2012). These accounts, however, rarely touch the issue how critical urban studies of post-socialist capitalism might be extended thematically (and theoretically) to the field of culture - as some proponents of the Los Angeles school argued earlier in the Anglo-American context (cf. Molotch 1996). Considering the opening up of both urban realities and academic life to the newest ideas coming from the West after 1990, it is not surprising that the creative city / creative capital thesis found an easy way into both the academia and urban policy-making in Eastern Europe since the early 2000s. Thus, this is a good moment to recall the creative city / creative capital line of argument here, and to evaluate it from the perspective of post-socialist urban development and urban governance.

\section{Creative capital, policy mobilities and the post-socialist city}

In the early 2000s it was Richard Florida who provided the impetus for the popularisation of the creative capital concept in urban studies. In his book, Cities and the creative class (Florida 2005) he argues that cities must restructure and redevelop themselves to serve the needs of the creative class and to attract creative capital; both of which are the ultimate goal, if a city attempts to perform well in the new global urban competition. If we consider different forms of capital discussed in the long history of social sciences literature, Florida's thesis is more-or-less focusing on human capital: for him, human capital and the creative class have complementary roles in urban and regional development (Florida et al. 2008). However, Florida's line of argument about the forms of capital is much fuzzier and more differentiated than this. In a recent paper, Tochterman (2012) looks at how continuous the ideas of neoliberal urban thinkers were from Jane Jacobs to Richard Florida. In this historiographical account, he triangulates Jacobs and Florida with David Harvey and shows that cultural development and the celebration of creativity is nothing else than the diversified consumerism of gentrification. What follows from this explanation is that this urban transformation process is ultimately about money capital: in Harvey's and Neil Smith's (2002) explanation it is the financial capital and the rent gap which drives urban regeneration in the capitalist world, and this fundamental working of the system did not change with the 'era' of creativity - if it exists at all. And to take another dimension of capital into account, it is important to underline that Florida's idea is also about personal capital, in two different respects. First, Hutton (2009) notes how Florida's most recent book, Who's Your City shifted his targeted audience from policy-makers at the spatial scale of the urban to those individuals of 'the final demand sector' (Hutton 2009: 335) who are in need of advice or in search for a self-help book (Shearmur 2009) about where they should move to live. Second, the whole story is about Richard Florida's personal capital. Peck (2005: 740) remarks for example that 'competition amongst [civic leaders] has subsequently worked to inflate Florida's speaking fees well 
into the five-figure range'. This phenomenon signifies quite well that the creativity idea resonated with the needs of urban policy-makers in the entrepreneurial era and the concept was able to travel easily between different places and geographical contexts.

To understand how urban policy ideas travel between spaces and places, critical urban studies have recently called for a policy mobilities approach (McCann \& Ward 2011). This way of understanding (Peck \& Theodore 2012) emphasises that how ideas travel in trans-local and cross-scalar networks cannot be captured by a simple diffusion approach (that of the Hägerstrandian tradition in human geography), but the mobility of concepts is always connected to different socio-spatial and institutional contexts (such as post-socialism in the case of this article). Policy ideas (like the creativity script) are always mutable mobiles: they change as they travel between different places with the help of human and non-human actors. Ultimately perhaps, methodological emphasis should be put on human actors (policy-makers and policy-implementers) who link together mental entities (ideas on creativity) and material entities (such as urban built environments) dynamically in order to renew certain urban neighbourhoods (cf. Jöns 2006).

The appreciative audience of urban policy-makers who capitalised on Richard Florida's ideas has been looked at by geographers grappling with urban policy mobilities with great interest. It might be quite easily followed by researchers how the ideas and practices change or not as they travel, because of the vast number of cases. The reason for this popularity of the creativity concept is described by Peck (2005: 764) as 'Both the script and the nascent practices of urban creativity are peculiarly well suited to entrepreneurialized and neoliberalized urban landscapes.' Prince (2010a: 876) presents an important contribution to the understanding how these practices are acted out in different urban contexts, as he looked especially at 'how a particular community of actors was cast as creative industry experts'. In policy mobility studies the origins of the creativity idea in the national public policy was traced back to the New Labour's third way politics in the United Kingdom at the end of the 1990s' (Prince 2010b). Although several studies looked at the Anglo-American policy transfer of creativity into different industrial settings of the 'core countries' (Atkinson \&Easthope 2009; Colomb 2012; Gibson et al. 2012; Peck 2012), less emphasis was put on the peripheral or semi-peripheral dependent economies outside the centres of global capitalism. A probable exception is the case of New Zealand: this country is informative in the sense that it was in the forefront of neoliberal market reforms and the import of fresh policy agendas, although it is located geographically in the periphery (cf. Larner et al. 2007; Prince 2010b). Eastern European cities were also studied marginally in this type of literature. The aim of this article then is to show several nodes through which the creativity idea found a way into networks of Hungarian academia and urban policy. In this sense, methodologically it is not a 'follow the policy' case study across different locales, as it looks only at one place, Hungary on various spatial scales.

Different groups have sought to capitalise on Richard Florida's ideas in the past decade in Hungary. One important group is the academia, the other being urban policy-makers and consultants. This part of the study focuses on the former and shows that among the academia we can observe a selective mobility of the creative capital / creative cities literature in Hungary. The next part of the study will focus on the scene of urban policy-making.

Academic papers have restructured the scientific field of social sciences in the sense that creativity has become a buzz-word. Most of the papers leave Richard Florida's theoretical approach untouched and unchallenged, they do not refer to its relevance for an Eastern European post-socialist context. The simple question to be asked is 'Where are the creative people located in space?' which is answered by the same methodology Richard Florida used in his studies (see for example Kovács 
et al. 2011; Rittgasszer 2009; Ságvári\&Lengyel 2008). It is true, however, that methodological challenges were deliberately addressed, because Hungarian statistical data were not available in a comparable classification as found in Anglo-American scientific papers. Another group of studies in urban history established the theoretical link between creativity and modernity in the late $19^{\text {th }}$ - early 20th century Budapest (Gyáni 2011).

Despite their less elaborated theoretical approach both of these strands have played an important role in better understanding of current Eastern European spatial processes, and have fundamentally questioned in an indirect way what Richard Florida (2008: 64) thinks about mega-regions 'that house the bulk of [...] innovation and production' in this part of the continent. On Florida's map of the creative Europe the Vienna-Budapest urban region extends from Graz to Przemyśl and from Brno to Budapest; whereas the Moravian city Brno is not a part of the Prague area (half of which being in the German territory). It is certainly true that there are no spatial-economic processes which would underscore this geographical imagination of Eastern Europe. For instance, the Hungarian studies mentioned here have proposed quite different maps based on real empirical work and mostly on official statistical data when measuring creative capital throughout the country.

Theoretical considerations of the creative capital thesis are rather less frequent in the Hungarian literature. This fact, combined with the overall positive evaluation of post-socialist neoliberal transformation (cf. Bockman\&Eyal 2002), means that individualistic-liberal standpoints of Florida found an easy way into the Hungarian academia. The leftist critique of the creative capital notion was missing from the literature until recently (Jelinek et al. 2013). There exists only one important 'critical' paper from the conservative right (Megadja 2008) which features the arguments of the Anglo-American literature (for an overview see Peck 2005) and in a confusing way the leftist critique is shown here out-of-context for underlining the rightist one. In a similar vein to the English case (Prince 2010b), third way politics drew on the creativity idea more enthusiastically: the Creative Atlas of Hungary (Ságvári\&Lengyel 2008) was published by the Demos Hungary Foundation think tank, the goals of which are bound up with those of its English counterpart organisation. For the leftist critiques of the creativity concept this publication and its connection to third way politics might be a serious challenge: its ideas are cast as coming from the left, thereby providing less room for manoeuvre for 'real' leftist thinkers.

\section{Spatial scales and variegation of the creative capital idea in Budapest}

This part of the article looks at how policy formulation on creativity is affected by actors at different spatial scales in Budapest. The simple reason for this approach is that the re-territorialisation of policies at different geographical levels has become an important aspect of current neoliberal capitalism (cf. Brenner 1999). Another aspect taken into account is that the creative city thesis in the Hungarian capital city has variegated manifestations, but each of them might be subsumed under the rubric of entrepreneurial urban governance, thus able to be integrated seamlessly with Brenner's conceptualisation of neoliberal change.

Rather than venturing a suggestion of a full picture of current and past urban creativity policies in Budapest, the article will look at three examples of how the creative capital idea has been adopted by policy-makers in the Hungarian capital city and how variegated this policy mobility is. The most important actors at different spatial scales in the three cases are summarized in Table 1. It is important 
to underline that the creative city scenario of the enterpreneuralised city is not always able to attract creative capital into the city. On the contrary, there are some trends in urban development practices which aim at obliterating creativity from certain neighbourhoods.

Table 1. Creative capital in Budapest: selected key actors at different spatial scales

\begin{tabular}{|c|c|c|}
\hline Spatial scale & Actor & Relation to creative capital \\
\hline \multirow[t]{4}{*}{ International } & EU framework programmes & $\begin{array}{l}\text { ACRE project: creativity and knowledge drives the urban } \\
\text { economy }\end{array}$ \\
\hline & $\begin{array}{l}\text { Leipzig Charter on Sustainable } \\
\text { European Cities }\end{array}$ & High-quality public spaces for attracting creative workforce \\
\hline & Transnational companies & $\begin{array}{l}\text { More knowledge-intensive activities appear in the city as a } \\
\text { consequence of reorganisation of value chains }\end{array}$ \\
\hline & URBACT & $\begin{array}{l}\text { Creative Clusters project: creativity is likely to be a driving } \\
\text { force in economic development of small urban centres }\end{array}$ \\
\hline \multirow[t]{2}{*}{ National } & Academics & Importing ideas on creative capital from other countries \\
\hline & $\begin{array}{l}\text { Urban rehabilitation pro- } \\
\text { grammes from EU funding }\end{array}$ & Functional upgrading through creative capital \\
\hline \multirow{2}{*}{$\begin{array}{l}\text { City of } \\
\text { Budapest }\end{array}$} & Urban consultants & For a $21^{\text {st }}$ century capital we need creativity in the city \\
\hline & Urban development strategy & $\begin{array}{l}\text { Budapest plays a leading role in developing the creative } \\
\text { economy }\end{array}$ \\
\hline \multirow[t]{4}{*}{ Districts } & Civil organisations & Establishing networks of creative people \\
\hline & New local regulations & $\begin{array}{l}\text { By adopting new regulations creative capital might be } \\
\text { captured in the district }\end{array}$ \\
\hline & Real estate developers & $\begin{array}{l}\text { Office developments are likely to attract enterprises in } \\
\text { creative industries }\end{array}$ \\
\hline & Urban development strategies & $\begin{array}{l}\text { There is competition for creative people and creative } \\
\text { industries, which will bring about growth and prosperity }\end{array}$ \\
\hline
\end{tabular}

Source: edited by the author.

The first example is coupling brownfield redevelopment with the creative city idea. Because of global historical path-dependence (the heritage of late $19^{\text {th }}$ century modernisation and the post-socialist de-industrialisation), brownfields represents a major challenge for recent urban development in the Hungarian capital city (Barta et al. 2006). As a consequence, for both Budapest and its autonomous districts, when facing urban redevelopment issues of brownfields, attraction of knowledge-intensive high added-value industries is seen as a solution. As regards these notions, emphasis is put on the financial capital aspect of creative capital, and on relations of creative capital and creative labour.

In district III, in Northwest Budapest the district's development strategy calls for a 'sustainable maximisation of the value production of the local economy'. This might be achieved by knowledgeintensive manufacturing industry for which neglected brownfields are potential locations. In this district at least there are positive examples of urban redevelopment: a real estate development by 
the software-technology firm Graphisoft is a good example of recent upgrading processes of the companies in transnational value chains (Glückler 2008) located on the former urban brownfields.

This development by Graphisoft is also featured at the international spatial scale of research: the ACRE (Accommodating Creative Knowledge - Competitiveness of European Metropolitan Regions within the Enlarged Union) project funded under the Sixth Framework Programme of the European Union shows it as a best practice for urban policy-makers how Graphisoft links research and development, urban regeneration and the international mobility of skilled persons (Musterd et al. 2010). Thus, this report has become an important non-human actor in circulation of ideas across Europe. At the national scale, Hungarian academics participating in this research project might be interpreted as actants combining material objects such as this policy guide and immaterial ideas of creative capital, arriving from other countries as well.

Because of different actors at different spatial scales, the creative capital represents a viable tool for brownfield rehabilitation also for not well-endowed districts in Budapest. At the district level, these are mostly office developments which are cast as capable for attracting enterprises in creative industries. Competition between Budapest's districts (quite a 'good' symptom of the entrepreneurial city) means that the real estate developers (mostly transnational companies, in many cases backed by transnational financial institutions) define urban futures of certain neighbourhoods during the negotiations with the districts (cf. Bodnar\&Molnar 2010), which might - in some cases - result in the obliteration of certain 'creative' activities in the city.

The district development strategies often 'recognise' their place in the urban competition for creative people. Consequently, they also focus on the human capital side of creativity and establish the links between creative labour and creative value added (in financial terms). There are cases in which Budapest's districts envisage full employment: attracting knowledge-intensive firms shall result in a trickle-down mechanism and skills-building for all workers. In fact, human capital might be easily transformed later to financial capital: according to the Graphisoft website market competition is almost a child's play after winning the competition for people. What is also typical of this entrepreneurial understanding of creativity from the districts' perspective is that the urban development strategies cannot capture the diversity of the urban creative economy: e.g. freelance artists working at home are completely invisible for and untouched by these urban strategies.

At the city level the urban consultants employed (or formerly employed) by the mayor may also play an important role in how districts perceive the function of creative people in the entrepreneurial city. For example, a recent booklet (also published by Demos Hungary) by a former consultant of the former liberal party mayor of Budapest emphasises that we ultimately need creativity in the city for Budapest to become a $21^{\text {st }}$ century capital (Bojár 2006). This understanding is also underpinned by the transnational networks of urban regions, such as URBACT at the spatial scale of the European Union. As an example, according to the Creative Clusters project's tenet creativity can be a driving force in the economic development of small urban centres, not only metropolitan regions (URBACT 2013). All of the districts in Budapest are then empowered and willing to see creativity as a solution for contemporary urban challenges and do not have to look at drawbacks to this approach.

While in the first example obliteration of the creative economy might happen in an indirect way by redeveloping 'underdeveloped' parts of the city, the second example shows a more direct link between the two phenomena. The cultural city centre redevelopment project of district XI (Újbuda) is not an unparalleled story, several others may to be found elsewhere in Budapest in the past years. The main driver of how and why creativity or culture appears in these types of redevelopment 
projects is the EU funding on urban redevelopment, mediated by national agencies. The regional operational programmes in Hungary (referring to the 2007-2013 programming period) had specific urban redevelopment actions which financially contribute to a functional upgrading of the inner cities. Many cities in Hungary (and Budapest districts) opted for projects which would raise the presence of the creative-cultural economy. The Újbuda cultural city centre project merges inner city redevelopment, creative economy and gentrification, an unpleasant combination from the perspective of the critique of the creative city thesis.

The action area of the Újbuda cultural city centre project is an upper-middle class residential area with a mostly turn-of-the-century built environment in the vicinity of the city centre on the Buda bank of the Danube. The goal of the project is to establish a cultural centre of the district with higher-standard cultural and recreational opportunities and to ensure 'more cultured' public space conditions. This is an understanding favoured at the European level urban policy-making by the Leipzig Charter on Sustainable European Cities: it considers high-quality public spaces as necessary conditions for attracting the creative 'workforce'. Public spaces will serve in this part of the city as scenes through which 'the cultural supply of the neighbourhood' are to be 'made available for broader social strata' (Újbuda 2013) - thereby implicitly referring to that certain forms of cultural consumption (such as visiting private galleries) are inaccessible for different social groups. A correlation between the urban built environment (public spaces) and reshaping the local economy is as simple as this - at least in the eyes of urban policy-makers.

The crucial instrument for this kind of fast renewal of the local cultural economy consists of a new local regulation about real estate management of shops in district property, located in the action area of the redevelopment project. Cultural consumption is shifted towards high-quality services (artisan shops, local galleries, upper-end bars and pubs etc.), thereby changing and pushing out the long-established local economy from this part of the city and favouring certain artist groups. The result might be achieved directly by not renewing contracts with shops not in the favoured economic sectors, or indirectly through gentrification that makes rents higher, and eliminates thereby the entrepreneurs at the lower end of the commercial spectrum.

This model of urban renewal might be interpreted positively. It is true that these urban transformations mobilise various forms of capital (Lugosi et al. 2010), and newly opened bars might be lively and important meeting points for the creative class. However, local social conflicts and negative social trends may also emerge. There is a need for social scientists to understand these social processes from a critical perspective in Budapest (cf. Földi 2006) and to move beyond the veil of a simple positive description of urban transformation - as in another case-study about an inner-city cultural renewal of Budapest (Csanádi et al. 2011).

The last case study in this paper is an indicative story about new urban exclusionary practices, directed towards one specific project on the local creative economy. The independent cultural centre Tüzraktár / Tüzraktér / Vizraktér (the name changed as the project was relocated) used to be an important bottom-up initiative by 'creative people' in the inner city of Budapest. The centre was established in 2005 at a brownfield location in a gentrifying neighbourhood of district IX. The squat-like milieu attracted many cultural projects and was an open space for the public for two years. In 2008, the group moved to district VI (also within the inner city): their new location used to be a school which did not function anymore because of a dropping number of children in this part of Budapest. This location was a 'cultural meeting point' featuring several studios for different artist groups, a pub and diverse cultural programmes accessible free of charge or for a moderate price. At that time the whole inclusionary initiative involved about 370 artists of different genres (Túzraktér 
2013). In 2011 the group was forced to move on and operated at a former bath in district II (Buda side, near the castle district).

Struggle for space started at the district VI location in 2011, resulting in the eviction of the group from the school. Although the whole cultural project was valued by the city government (it was awarded the Pro Urbe prize in 2010), in early 2011 the district government (which owned the school-building) declared the building's physical condition to be life threatening. The district published a tender for the renovation and further use of the school with no proper result (the renovation of the building would have cost so much that it was neither profitable for a private investor nor for a non-profit organisation). The Tüzraktér group launched discussions with the local government about a long-term use concept which was declined by the local government with the argument that this use would disturb nearby residents (with no mention of the life-threatening conditions at all). As the discussions fell through (supposedly neither party was too keen on reaching a compromise) and the renting contract expired the police cleared out and sealed the building in June 2011 despite several pro-Túzraktér demonstrations. After more than a year, a new group (using most probably the network capital the organisers have towards decision makers of the district) opened up at the same place with a more exclusionary higher-end restaurant and club, with some studios, as before. This example illustrates the opportunities of urban governance in both enabling and disabling creative capital and creative labour; opposed to David Harvey's interpretation that the entrepreneurial city is a burden in most cases as it narrows opportunities for the local governments. Here in Budapest, the erasure of (at least of certain actors of the) creative economy from a certain neighbourhood might be 'successful' in spite of the general urban policy favouring creative industries and creative people. Obliteration of creativity by such practices is for sure not something Richard Florida envisaged when writing his bestsellers on how urban policy should be transformed in the 'creative age'.

\section{Conclusion}

Urban struggles for space affect all people in the entrepreneurial city. These struggles might be interpreted based on the creativity thesis: for socially marginalised people it is their everyday creativity by which they are able to survive (Wilson\&Keil 2008), for creative workers it is also an everyday reality to be in a precarious labour position (Siebert\&Wilson 2013). These phenomena prevail not only in the core countries and urban cores of contemporary capitalism, but also in the cities of Eastern European semi-periphery.

For the critical social scientists it has become a moral imperative to take back the term of creativity from liberal-individualistic standpoints like that of Richard Florida, because this is the only way to counter ideas and practices of the entrepreneurial city at different spatial scales. The means of this struggle are manifold. Firstly, policy mobilities research might inform social scientists, policy-makers, activists and local residents how certain forms of urban governance show up and function in different geographical settings at different spatial scales. In the context of this paper it is only possible to cast light on the shadowy negative effects of the creativity script by using the term 'creativity'. Moreover, the article has attempted to show based on a study on Budapest that the creative capital idea and differentiating between forms of creative capital are helpful in describing current urban transformations and their underlying motives. Secondly, the creativity term is also to be used for positive alternatives, not only for criticism. Borén and Young (2013) emphasise the strength of the creativity thesis in opening up 'new conceptual spaces' where artists, citizens and academics 
may contest elite and urban planners' visions of creativity. How these spaces and places function in contemporary Budapest (as some examples do exist) might be a highly-needed empowering and emancipatory project for the future.

\section{Acknowledgements}

Previous versions of this paper were presented at the July 2013 summer school 'Between (Post)Socialism and (Neo)Liberalism' in Sofia, and at the 'Warsaw Regional Forum 2013'. I would like to thank for all the helpful comments and questions at these two gatherings, which helped to consolidate the argument of this article. All remaining errors are my own.

\section{References}

Atkinson, R., Easthope, H., 2009. The consequences of the creative class: The pursuit of creativity strategies in Australia's cities. International Journal of Urban and Regional Research, vol. 33, no. 1, pp. 64-79.

Barta, Gy., Beluszky, P., Czirfusz, M., Győri, R., Kukely, Gy., 2006. Rehabilitating the brownfield zones of Budapest. Pécs: Centre for Regional Studies of the Hungarian Academy of Sciences.

Bockman, J., Eyal, G., 2002. Eastern Europe as a laboratory for economic knowledge: The transnational roots of neoliberalism. American Journal of Sociology, vol. 108, no. 2, pp. 310-352.

Bodnár, J., 2001. Fin de millénaire Budapest: metamorphoses of urban life. Minneapolis-London: University of Minnesota Press, $222 \mathrm{pp}$.

Bodnar, J., Molnar, V., 2010. Reconfiguring private and public: State, capital and new housing developments in Berlin and Budapest. Urban Studies, vol. 47, no. 4, pp. 789-812.

Bojár, I.A., 2006. Budapest, a kreatív város - a lehetőségek kapujában. Budapest: DEMOS Magyarország Alapítvány, $60 \mathrm{pp}$.

Borén, T., Young, C., 2013. Getting creative with the "creative city"? Towards new perspectives on creativity in urban policy. International Journal of Urban and Regional Research, vol. 37, no. 5, pp. 1799-1815.

Brenner, N., 1999. Globalisation as reterritorialisation: The re-scaling of urban governance in the European Union. Urban Studies, vol. 36, no. 3, pp. 431-451.

Colomb, C., 2012. Pushing the urban frontier: temporary uses of space, city marketing, and the creative city discourse in 2000s Berlin. Journal of Urban Affairs, vol. 34, no. 2, pp. 131-152.

Csanádi, G., Csizmady, A., Olt, G., 2011. Social sustainability and urban renewal on the example of Inner-Erzsébetváros in Budapest. Society and Economy, vol. 33, no. 1, pp. 199-217.

Egedy, T., Kovács, Z., 2010. Budapest: A great place for creative industry development? Urbani izziv, vol. 21, no. 2, pp. 127-138.

Florida, R., 2005. Cities and the creative class. London: Routledge, $198 \mathrm{pp}$.

Florida, R., 2008. Who's your city? How the creative economy is making where to live the most important decision of your life. New York: Basic Books, 374 pp.

Florida, R., Mellander, C., Stolarick, K., 2008. Inside the black box of regional development - human capital, the creative class and tolerance. Journal of Economic Geography, vol. 8, no. 5, pp. 615-649. 
Földi, Zs., 2006. Neighbourhood dynamics in inner-Budapest: a realist approach. Utrecht: Koninklijk Nederlands Aardrijkskundig Genootschap, 345 pp.

Földi, Zs., van Weesep, J., 2007. Impacts of globalisation at the neighbourhood level in Budapest. Journal of Housing and the Built Environment, vol. 22, no. 1, pp. 33-50.

Gibson, C., Gallan, B., Warren, A., 2012. Engaging creative communities in an industrial city setting: A question of enclosure. Gateways: International Journal of Community Research and Engagement, vol. 5, no. 1, pp. 1-15.

Glückler, J., 2008. „Service Offshoring“. Globale Arbeitsteilung und regionale Entwicklungschancen. Geographische Rundschau, vol. 60, no. 9, pp. 36-42.

Gyáni, G., 2011. A kreatív föváros: Budapest a 19-20. század fordulóján. História, vol. 33, no. 1-2, pp. 34-38.

Harvey, D., 1989. From managerialism to entrepreneurialism: The transformation in urban governance in late capitalism. Geografiska Annaler. Series B, Human Geography, vol.71, no. 1, pp. 3-17.

Hutton, T., 2009. Who's your city? How the creative economy is making where to live the most important decision of your life - by Richard Florida. Economic Geography, vol. 85, no. 3, pp. $335-336$.

Jelinek, Cs., Bodnár, J., Czirfusz, M., Gyimesi, Z. (eds.), 2013. Kritikai városkutatás. Budapest: L'Harmattan, $507 \mathrm{pp}$.

Jöns, H., 2006. Dynamic hybrids and the geographies of technoscience: discussing conceptual resources beyond the human/non-human binary. Social \& Cultural Geography, vol. 7, no. 4, pp. 559-580.

Kovács, Z., Egedy, T., Szabó, B., 2011. A kreatív gazdaság földrajzi jellemzői Magyarországon. Tér és Társadalom, vol. 25, no. 1, pp. 42-62.

Larner, W., Molloy, M., Goodrum, A., 2007. Globalization, cultural economy, and not-so-global cities: the New Zealand designer fashion industry. Environment and Planning D: Society and Space, vol. 25, no. 3, pp. 381-400.

Lugosi, P., Bell, D., Lugosi, K., 2010. Hospitality, culture and regeneration: urban decay, entrepreneurship and the "ruin" bars of Budapest. Urban Studies, vol. 47, no. 14, pp. 3079-3101.

McCann, E., Ward, K., 2011. Mobile urbanism: cities and policymaking in the global age. Minneapolis: University of Minnesota Press, 213 pp.

Megadja, G., 2008. A kreatív osztály szárnyalása? Kommentár, no. 4, pp. 54-60.

Molotch, H., 1996. L.A. as design product: how art works in a regional economy. [in:] E.W. Soja, A.J. Scott (eds.),The city: Los Angeles and urban theory at the end of the twentieth century, Berkeley: University of California Press, pp. 225-275.

Musterd, S., Brown, J., Lutz, J., Gibney, J., Murie, A. (eds.), 2010. Making creative-knowledge cities. A guide for policy makers. Amsterdam: Amsterdam Institute for Social Science Research (AISSR), University of Amsterdam, $64 \mathrm{pp}$.

Nagy, E., Timár, J., 2012. Urban restructuring in the grip of capital and politics: Gentrification in East-Central Europe. [in:] T. Csapó, A. Balogh (eds.), Development of the settlement network in the Central European countries, Berlin-Heidelberg: Springer, pp. 121-135.

Peck, J., 2005. Struggling with the creative class. International Journal of Urban and Regional Research, vol. 29, no. 4, pp. 740-770.

Peck, J., 2012. Recreative city: Amsterdam, vehicular ideas and the adaptive spaces of creativity policy. International Journal of Urban and Regional Research, vol. 36, no. 3, pp. 462-485. 
Peck, J., Theodore, N., 2012. Follow the policy: a distended case approach. Environment and Planning A, vol. 44, no. 1, pp. 21-30.

Petrovici, N., 2012. Workers and the city: Rethinking the geographies of power in post-socialist urbanisation. Urban Studies, vol. 49, no. 11, pp. 2377-2397.

Prince, R., 2010a. Fleshing out expertise: The making of creative industries experts in the United Kingdom. Geoforum, vol. 41, no. 6, pp. 875-884.

Prince, R., 2010b. Policy transfer as policy assemblage: making policy for the creative industries in New Zealand. Environment and Planning A, vol. 42, no. 1, pp. 169-186.

Rittgasszer, I., 2009. Kreativ kistérségek Magyarországon. Tér és Társadalom, vol. 23, no. 4, pp. $27-44$.

Ságvári, B., Lengyel, B., 2008. Kreativ atlasz. A magyarországi kreatív munkaerö területi és időbeli változásáról. Budapest: DEMOS Magyarország Alapítvány, 84 pp.

Shearmur, R., 2009. Who's your city? How the creative economy is making where you live the most important decision of your life by Richard Florida. Canadian Geographer / Le Géographe canadien, vol. 53, no. 3, pp. 379-381.

Siebert, S., Wilson, F., 2013. All work and no pay: consequences of unpaid work in the creative industries. Work, Employment \& Society, vol. 27, no. 4, pp. 711-721.

Smith, N., 2002. New globalism, new urbanism: Gentrification as global urban strategy. Antipode, vol. 34 , no. 3, pp. 427-450.

Sýkora, L., Bouzarovski, S., 2012. Multiple transformations conceptualising the post-communist urban transition. Urban Studies, vol. 49, no. 1, pp. 43-60.

Tochterman, B., 2012. Theorizing neoliberal urban development. A genealogy from Richard Florida to Jane Jacobs. Radical History Review, no. 112, pp. 65-87.

Tüzraktér, 2013. Tüzraktér független kulturális központ. http://tuzrakter.hu/mi.html [30 November 2013].

Újbuda, 2013. Kulturális városközpont Újbudán. http://www.ujbuda.hu/kvk_projekt.php [30 November 2013].

URBACT, 2013. Creative Clusters. http://urbact.eu/en/projects/innovation-creativity/creative-clusters/homepage/ [30 November 2013].

Wilson, D., Keil, R., 2008. The real creative class. Social \& Cultural Geography, vol. 9, no. 8, pp. 841-847. 